International Research Journal of Management, IT \& Social Sciences
Available online at https://sloap.org/journals/index.php/irjmis/
Vol. 6 No. 4, July 2019, pages: 118 126
ISSN: 2395-7492
https://doi.org/10.21744/irjmis.v6n4.664

\title{
The Analysis of Factors that Effect Business Development and Income of MSMEs in Denpasar City
}

I.B. Hendra Prawira D. ${ }^{a}$

Heny Urmila Dewi ${ }^{\text {b }}$

\section{Article history:}

Received: 18 March 2019

Accepted: 31 May 2019

Published: 03 July 2019

\section{Keywords:}

business development;

capital;

labor;

MSME income;

social capital;

\begin{abstract}
The population in this study were all MSMEs players in the city of Denpasar, amounting to 30,840 MSMEs and the number of samples used as many as 100 MSME actors with a method of determining stratified proportional sampling. The data analysis technique used is path analysis. The results of the analysis show that: 1) capital, labor, and social capital have a positive and significant effect on the development of MSMEs in Denpasar City. This means that the availability of capital, the working hours of MSME actors and the application of the three dimensions of social capital namely trust, social norms, and social networks are very influential on the development of the MSME business sector. 2) Capital, labor, social capital, and business development have a positive and significant effect on the income of SMEs in Denpasar City. This means that capital ownership, labor, social capital and the development of MSMEs will have a positive and significant impact on increasing the income of MSME players. 3) Business development is a variable that mediates the influence of capital, labor and social capital on the income of SMEs in Denpasar City.
\end{abstract}

2395-7492@ Copyright 2019. The Author. This is an open-access article under the CC BY-SA license (https://creativecommons.org/licenses/by-sa/4.0/) All rights reserved.

\section{Author correspondence:}

I.B. Hendra Prawira D.,

Faculty of Economics and Business, Udayana University, Denpasar, Bali-Indonesia.

Email address: rasumaputri80@gmail.com

\section{Introduction}

Amid existing economic developments, MSMEs in Denpasar City which are considered as pillars of the national economy in terms of quantity has not been balanced with adequate quality improvements. The problem faced was low productivity and competitiveness, which caused a large gap between MSMEs and large-scale businesses. Increased productivity is urgently needed to encourage increased competitiveness of MSMEs to be able to compete, both in the domestic and global economy.

\footnotetext{
a Faculty of Economics and Business, Udayana University, Denpasar, Indonesia ${ }^{\mathrm{b}}$ Faculty of Economics and Business, Udayana University, Denpasar, Indonesia
} 
The crucial prognosis faced by MSMEs in Denpasar City is the limited access of MSMEs to productive resources, especially towards the capital, technology, information, and markets. The limited access of MSMEs to capital has made it difficult to increase business capacity and develop competitive products. The problem of access to MSME capital as a source of causes is precise because of the limitations of MSMEs themselves, both in terms of marketing, mastery of technology and information, and poor business management.

Basically, the existence of MSMEs in Denpasar City has a high socio-economic impact. MSMEs have been able to improve people's lives and have an impact on the surrounding environment. Its existence has provided additional employment to the community. MSMEs are believed to be used as access to reduce unemployment and become a source of community income.

Income is the overall income received by workers in the form of physical or non-physical during work or business (Kurniawan, 2016). Revenue is one indicator to measure the level of prosperity and welfare of the community so that the size of economic income reflects economic progress. A good economy will provide the welfare of the community in the area concerned (Artana Yasa, 2015). The higher the income a person gets, the better his life will be. Income plays a role in determining the level of consumption of the community (Dewi, 2015; Suartawan \& Artini, 2019). In the business world, the level of income earned is not the same, this is what often triggers the income gap that occurs in the community. The income received by each individual or community group is very dependent on the ownership of production factors.

One of the factors that influence income is the development or failure of a business. Business development in this study is seen from the sales volume. Sales volume is the number of products or services that can be sold. Mulyadi (2005), states that sales volume is a measure that shows the amount or amount of goods or services sold. The results of the empirical study of Astuti (2005), state that business volume has a positive effect on income earned by entrepreneurs. That is, the greater the volume of business or sales of a product, the greater the income that the entrepreneur gets. Similar results were also confirmed by the results of Eggert et al., (2014), states that sales volume has a positive effect on business income. This will happen when entrepreneurs are able to implement the right strategy in the face of product competition.

The efficient and effective use of production factors will affect business development and increase the welfare of business actors. One of the crucial production factors that influence business development and income is capital. Operational capital is an element of assets that is very important in the company and affects business volume. Without capital, the company cannot fulfill the funding needs to carry out its activities. The research results of Sriwati (2011), state that capital has a positive effect on the increase in sales volume. That is, the higher the capital owned, the higher the business volume of the entrepreneur. Good capital management can affect sales, and continuity of production process activities.

Capital as one of the inputs or factors of production that can affect income. The results study of the Pariartha (2007), state that the more capital a person has, the higher the opportunity to produce more output. Working capital has two functions, namely sustaining production activities and closing funds or fixed expenditures that are not directly related to production and sales (Raheman \& Nasr, 2007). MSMEs are categorized as small businesses and do not choose to work even with not so much capital (Hyman, 2012).

Nevertheless, the facts in the field show that in the effort to develop MSMEs, there are still obstacles related to the source of capital. Limited capital access and increasingly difficult procedures are one of the major obstacles felt by MSME entrepreneurs in terms of funding (Parinduri, 2016). Based on the results of Yanutya (2013), states that partially capital has a positive and significant effect on income. A business will need capital continuously to develop the business.

Part of other production factors that affect business development and income is labor. Labor is an important factor that influences business development and income. Labor is another driving factor for input factors, without the presence of labor, other factors of production will not matter. The workforce in this study is seen from the number of working hours of employers. Based on the results of research by Golden (2012), stated that working hours have a positive influence on business volume. This means that the higher the working hours, the higher the capacity of products that can be created for sale.

The workforce is a driver in an effort to achieve certain goals to be achieved, therefore each company seeks to combine the use of appropriate labor inputs in order to increase its liquidity through increased production, and ultimately to maximize income (Kasmir, 2008). According to Sumarsono (2013), labor has a positive and significant effect on income generation. The more workers who work, the income of employers will also increase. Furthermore, Yuniartini (2013), states that labor has a positive and significant effect on income. The results research of Putra \& Sudirman (2015) and Prakoso (2013), state that labor has a positive and significant effect on income. This means that

Prawira D., I. H., \& Dewi, H. U. (2019). The analysis of factors that effect business development and income of MSMEs in Denpasar city. International Research Journal of Management, IT and Social Sciences, 6(4), 118-126. https://doi.org/10.21744/irjmis.v6n4.664 
when the workforce used increases the demand that can be fulfilled is greater and the income received by the company will also increase.

Efforts to support the development of MSMEs are becoming more advanced and developing, so we need to pay attention to aspects of social capital, in addition to their financial aspects. Social capital is a forum for achieving social welfare should not only be a routine activity for businesses run by entrepreneurs but also must be able to accommodate various problems and do problem-solving. The main problems faced by MSME entrepreneurs in Denpasar City are three, namely natural problems, human resource problems, and management problems.

Social capital is a social resource that can be seen as an investment to get new resources in society. Social capital plays an important role in the functioning and strengthening the economic resilience of modern society (Fukuyama, 1995). The weak level of social capital in the community can lead to various problems and irregularities in the business world. Social capital is a series of processes of human relations supported by networks, social norms, and beliefs that enable efficiency and effectiveness of coordination and cooperation for mutual benefit, emphasizing a broader dimension on the basis of togetherness, and in which values and norms that grow and adhere to (Thobias et al., 2013).

\section{Literature Review and Hypothesis Development}

The MSME sector is one of the means to develop the creativity of each community that is able to make a major contribution to the welfare and economy of the community. The MSME sector of each region has a different type, this is influenced by the characteristics of each resource that is owned by each region. The existence of the industrial sector plays an important role in economic development, especially increasing per capita income while also guaranteeing the distribution of income that is evenly distributed throughout the community.

Income level is influenced by the use of several factors such as the development of capital business, labor, and social capital. The development of MSME businesses can contribute fairly well to the income of MSME actors as an effort in overcoming the problems that are often faced such as high levels of poverty, large numbers of unemployed people, and inequality in income distribution (Basar, 2015; Dewi et al., 2018; Korry \& Suartini, 2019). Business development in this study is proxied by business volume. In accordance with the results of the empirical study Astuti (2005) states that business volume has a positive effect on income earned by entrepreneurs. That is, the greater the volume of business or sales of a product, the greater the income that the entrepreneur gets. Similar results were also confirmed by the results of Eggert et al., (2014), states that sales volume has a positive effect on business income. This will happen when entrepreneurs are able to implement the right strategy in the face of product competition.

Working capital will affect business volume. Operational capital is one element of assets that is very important in the company. Because without capital, the company cannot fulfill the funding needs to carry out its activities. The research results of Sriwati (2011), state that capital has a positive effect on the increase in sales volume. That is, the higher the capital owned, the higher the business volume of the entrepreneur. With good operational capital management can affect sales, it can be seen that if the company has enough cash then the company can finance the daily activities of the production process and can maintain the continuity of the company. The results of Puspitasari $e t$ al., (2012) and Widyamukti et al., (2018), research also found that capital has a significant positive effect on the sales volume of business.

Capital as one of the inputs or factors of production that can affect income but not the only factor that can increase income (Suparmoko, 1986). If capital increases, productivity, and income will also increase (Sukirno, 2012; Kustina et al., 2018). The results study of Pariartha (2007), state that the more capital a person has, the higher the opportunity to produce more output. Working capital has two functions, namely sustaining production activities and closing funds or fixed expenditures that are not directly related to production and sales (Raheman \& Nasr, 2007; Lisa \& Hermanto, 2018).

Capital can increase production capacity and increase the income that entrepreneurs will receive (Dietsch, 2003; Narasimhulu, 2019). MSMEs are categorized as small businesses and do not choose to work even with not so much capital (Hyman, 2012). Nevertheless, the facts in the field show that in the effort to develop MSMEs, there are still obstacles related to the source of capital. Limited capital access and increasingly difficult procedures are one of the big obstacles felt by MSME entrepreneurs in terms of funding. The capital structure of the company will influence the existence of the company in the midst of increasingly rapid competition (Ovtchinnikov, 2010).

A business will need capital continuously to develop a business that becomes a liaison tool, materials, and services used in production to obtain sales results (Ahmad, 2004; Pemayun \& Suryanata, 2019). Based on the results research of Yanutya (2013), states that partially capital has a positive and significant effect on income. This is also in line with the results of the research of Adhiatma (2014), which states that capital partially has a positive influence on income. 
Labor is an important factor that influences business development and income. Labor is another driving factor for input factors, without the presence of labor, other factors of production will not matter. The workforce in this study is seen from the number of working hours of employers. Based on the results of research by Golden (2012), stated that working hours have a positive influence on business volume. This means that the higher the working hours, the higher the capacity of products that can be created for sale.

Increasing labor productivity will encourage increased production so that income will also increase. According to Sukirno (2015), labor has a positive and significant effect on income generation. The more workers who work, the income of employers will also increase. This is in accordance with the results of research by Sumarsono (2013), which states that the number of workers has a positive effect on income. That is, the more labor is used, the greater the chance to get higher income.

The results of this study are also supported by Yuniartini (2013) which states that labor has a positive and significant effect on income. The results research of Putra \& Sudirman (2015) and Prakoso (2013), state that labor has a positive and significant effect on income. This means that when the workforce used increases the demand that can be fulfilled is greater and the income received by the company will also increase.

Social capital has a positive and significant relationship to business development. The application of the dimensions of social capital, namely beliefs, norms, and social networks, plays an important role because it can contribute to business development efforts and simultaneously empower local communities (Chou, 2006; Bire et al., 2019). According to Badaruddin (2006), trust is an effort to grow and build social capital that requires a process, time and commitment and the ability to build social capital in a community is one effort to be able to empower the community, both socially and economically.

Understanding of the values or social norms embedded in the community will create a community that is harmonious and peaceful so that activities or businesses that run can run well. Paskarina (2007), states that economic productivity can be encouraged and strengthened by creating conditions of social stability. Therefore, good behavior plays an important role in the development of a business, so it will motivate to develop business towards a better one. Furthermore, the existence of social networks is a catalyst for trust and norms as part of social capital in developing businesses.

\section{Research Hypothesis}

a) Capital, labor, and social capital have a positive effect on the development of MSMEs in Denpasar City.

b) Capital, labor, social capital, and business development have a positive effect on the income of SMEs in Denpasar City.

c) Business development mediates the effect of capital, labor and social capital on the income of SMEs in Denpasar City.

\section{Materials and Methods}

The location of the study was conducted in Denpasar City. The reason for choosing Denpasar City is because in the city of Denpasar there is still an information gap that affects the development of MSMEs, meaning that information that influences MSMEs in business development and increased income in an effort to achieve prosperity does not yet exist and is not yet available.

The population used in this study were all MSMEs in the city of Denpasar, amounting to 30,840 MSMEs (Denpasar Cooperative and MSME Service Office, 2018). By using the Slovin formula, the population is 30,840 and the error limit is 10 percent, then a sample of 100 SMEs in Denpasar City is obtained. In order for the population to be represented equally by region, then the stratified proportional sampling method.

The data analysis technique used in this study is Path Analysis. The structural equation can be made as follows:

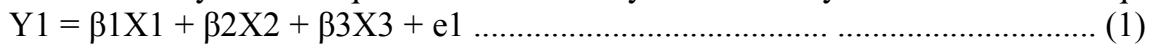

$\mathrm{Y} 2=\beta 4 \mathrm{X} 1+\beta 5 \mathrm{X} 2+\beta 6 \mathrm{X} 3+\beta 7 \mathrm{Y} 1+\mathrm{e} 2$

Information:

$\mathrm{Y} 2$ = income of MSMEs

$\mathrm{Y} 1$ = business development

$\mathrm{X} 1$ = capital

$\mathrm{X} 2$ = labor

Prawira D., I. H., \& Dewi, H. U. (2019). The analysis of factors that effect business development and income of MSMEs in Denpasar city. International Research Journal of Management, IT and Social Sciences, 6(4), 118-126. https://doi.org/10.21744/irjmis.v6n4.664 
$\mathrm{X} 3$ = social capital

$\beta 1 \ldots \beta 7=$ Regression coefficients for each variable $X$

$\mathrm{e} 1, \mathrm{e} 2=$ error term

\section{Results and Discussions}

Testing the hypothesis of the influence of capital, labor and social capital on the development of MSMEs in Denpasar City. One equation testing was conducted to see the effect of capital, labor and social capital on the development of MSMEs in Denpasar City directly, the results of the regression test are presented in Table 1.

Table 1

Regression test results of capital, labor and social capital towards the development of MSMEs in Denpasar City

\begin{tabular}{|c|c|c|c|c|c|c|}
\hline \multirow[b]{2}{*}{ Model } & & \multicolumn{2}{|c|}{ Unstandardized Coefficients } & $\begin{array}{c}\text { Standardized } \\
\text { Coefficients }\end{array}$ & \multirow[b]{2}{*}{$\mathrm{t}$} & \multirow[b]{2}{*}{ Sig. } \\
\hline & & $\mathrm{B}$ & Std. Error & Beta & & \\
\hline 1 & (Constant) & -96.185 & 19.348 & & -4.971 & .000 \\
\hline & Modal & 14.981 & 3.838 & 439 & 3.886 & .000 \\
\hline & tenaga kerja & .185 & .075 & .279 & 2.467 & .016 \\
\hline & modal sosial & 1.009 & .320 & .035 & 3.163 & .004 \\
\hline
\end{tabular}

Primary data, 2019

Table 1 shows that the capital variable (X1) has a sig value. $0,000<0,05$, this means that capital has a positive and significant effect on the development of MSMEs in Denpasar. Labor variable (X2) with sig value. $0.016<0.05$, this means that labor has a positive and significant effect on the development of MSMEs in Denpasar City. Social capital variable (X3) with sig value. $0.004<0.05$, this means that social capital has a positive and significant effect on the development of MSMEs in Denpasar City.

3.1 Testing the hypothesis of the influence of capital, labor, social capital and business development on the income of SMEs in Denpasar City

Tests for equation two are done to see the effect of capital, labor, social capital and business development on the income of MSME players in Denpasar City directly, the results of the regression test are presented in Table 2.

Table 2

The results of the regression tests of capital, labor, social capital and business development on the income of MSME players in Denpasar City

\begin{tabular}{|c|c|c|c|c|c|c|}
\hline \multirow{2}{*}{\multicolumn{2}{|c|}{ Model }} & \multicolumn{2}{|c|}{ Unstandardized Coefficients } & \multirow{2}{*}{$\begin{array}{l}\text { Standardized } \\
\text { Coefficients } \\
\text { Beta }\end{array}$} & \multirow[b]{2}{*}{$\mathrm{t}$} & \multirow[b]{2}{*}{ Sig. } \\
\hline & & B & Std. Error & & & \\
\hline \multirow[t]{5}{*}{1} & (Constant) & .079 & .288 & & .276 & 784 \\
\hline & Modal & .823 & .055 & .718 & 15.028 & .000 \\
\hline & tenaga kerja & .004 & .001 & .179 & 3.873 & .000 \\
\hline & modal sosial & .039 & .015 & .060 & 2.600 & .042 \\
\hline & pengembangan usaha & .004 & .001 & .117 & 2.905 & .005 \\
\hline
\end{tabular}

Primary Data, 2019

Table 2 shows that the capital variable (X1) has a sig value. $0,000<0,05$, this means capital has a positive and significant effect on the income of MSMEs in Denpasar. Labor variable (X2) with sig value. $0,000<0,05$, this means that labor has a positive and significant effect on the income of MSMEs in Denpasar City. Social capital variable (X3) with sig value. $0.042<0.05$, this means that social capital has a positive and significant effect on the income of SMEs 
in Denpasar City. Business development variable (Y1) with sig value. $0.005<0.05$, meaning that business development has a positive and significant effect on the income of SMEs in Denpasar City.

\subsection{Path Analysis Test Results}

Based on the results of the study it can be seen the relationships between research variables which are the path coefficients in this study. Path coefficients can be made in the form of path diagrams (Suyana, 2016). The model can also be expressed in structural equations, namely:

Structural Equations 1

$\mathrm{Y} 1=0.439 \mathrm{X} 1+0.279 \mathrm{X} 2+0.035 \mathrm{X} 3$

Structural Equations 2

$\mathrm{Y} 2=0.718 \mathrm{X} 1+0.179 \mathrm{X} 2+0.060 \mathrm{X} 3+0.117 \mathrm{Y} 1$

\section{Standard Estimated Error Value}

To find out the value of e1 which shows the number of the variance of business development variables that are not explained by capital, labor and social capital, calculated using the formula:

$$
\begin{aligned}
& e_{1}=\sqrt{1-R_{1}^{2}} \\
& e_{1}=\sqrt{1-0,466} \\
& e_{1}=0,731
\end{aligned}
$$

Whereas to find out the value of $\mathrm{e}_{2}$ which shows the variance of the variable income of MSME actors that is not explained by capital, labor, social capital, and business development, it is calculated using the formula:

$$
\begin{aligned}
& \mathrm{e}_{2}=\sqrt{1-\mathrm{R}_{2}^{2}} \\
& \mathrm{e}_{2}=\sqrt{1-0,918} \\
& \mathrm{e}_{2}=0,286
\end{aligned}
$$

\section{Examination of Model Validity}

To check the validity of the model, there are indicators to carry out checks, namely the coefficient of total determination of the results as follows:

$$
\begin{aligned}
R_{m}^{2} & =1-e_{1}^{2} \cdot e_{2}^{2} \\
& =1-(0,731)^{2}(0,286)^{2} \\
& =1-(0,534)(0,081) \\
& =1-0,043 \\
& =0,957
\end{aligned}
$$

Based on the results of the calculation of the total determination coefficient, it is obtained that the diversity of data that can be explained by the model is 0.957 or in other words the information contained in the data is 95.7 percent can be explained by the model, while the remaining 4.3 percent is explained by other variables which are not in the model.

\section{Indirect Effects}

The results of testing the direct effect, indirect effects and total influence are shown in Table 3.

Prawira D., I. H., \& Dewi, H. U. (2019). The analysis of factors that effect business development and income of MSMEs in Denpasar city. International Research Journal of Management, IT and Social Sciences, 6(4), 118-126. 
Table 3

Indirect effect

\begin{tabular}{cccc}
\hline Variable & \multicolumn{2}{c}{ Effect } & \multirow{2}{*}{ Total Effect } \\
\cline { 2 - 3 } Relationships & Direct & Indirect through Y1 & 0,439 \\
\cline { 2 - 3 } $\mathrm{X} 1 \longrightarrow \mathrm{Y} 1$ & 0,439 & - & $0,718+0,051=0,769$ \\
$\mathrm{X} 1 \longrightarrow \mathrm{Y} 2$ & 0,718 & $0,439 \times 0,117=0,051$ & 0,279 \\
$\mathrm{X} 2 \longrightarrow \mathrm{Y} 1$ & 0,279 & - & $0,179+0,032=0,211$ \\
$\mathrm{X} 2 \longrightarrow \mathrm{Y} 2$ & 0,179 & $0,279 \times 0,117=0,032$ & 0,035 \\
$\mathrm{X} 3 \longrightarrow \mathrm{Y} 1$ & 0,035 & - & $0,060+0,004=0,064$ \\
$\mathrm{X} 3 \longrightarrow \mathrm{Y} 2$ & 0,060 & $0,035 \times 0,117=0,004$ & 0,117 \\
$\mathrm{Y} 1 \longrightarrow \mathrm{Y} 2$ & 0,117 & - & \\
\hline
\end{tabular}

Primary Data, 2019

Coefficient standardized values are used to obtain coefficients that have the same base unit, so that they can be compared directly between exogenous variables, in their respective effects on endogenous variables. Based on Figure 5.1 shows the error value of the estimated standard e 1 of 0.731 and e 2 of 0.286 . Exogenous variables which have a greater influence on endogenous variables can be seen from the size of each coefficient (beta) regressor.

The capital coefficient value for business development is 0.439 , meaning that if capital increases by 1 rupiah, business development will increase by 0.439 percent. The labor coefficient of 0.279 means that if the business hours of a business actor increase by 1 hour, business development will increase by 0.279 percent. The results show that social capital has a positive and significant effect on the development of MSMEs in Denpasar City, which means that the better the application of the three dimensions of social capital, the more business will be developed.

The capital coefficient value of the income of MSME players is 0.718 , meaning that if capital increases by 1 rupiah, the income of MSME players will increase by 0.718 percent. The labor coefficient is 0.179 , which means that if the business hours of a business actor increase by 1 hour, the income of MSME players will increase by 0.179 percent. Social capital has a positive and significant effect on the income of MSME players in Denpasar City, meaning that the better the application of social capital, the better the welfare felt by MSME actors. The coefficient of business development towards the income of SMEs is 0.117 , which means that if business development increases by 1 percent, the income of MSME players will increase by 0.117 percent.

\section{Conclusion}

For the Government, it is expected that the results of this study can be input into the making of future policies, especially in paying attention to the welfare aspects of MSME actors in developing businesses. To increase income, it can be done by providing capital assistance from the government or from bank financial institutions or non-bank financial institutions, considering that MSMEs have considerable potential in terms of income so that they will be more prosperous for the community. One of them is by simplifying loan procedures.

For SMEs, it is expected that the results of this study can be a reflection and as an evaluation material in an effort to implement aspects of social capital well, especially in building good relationships with various parties, including consumers, fellow entrepreneurs, communities and other parties. To increase labor factors greatly affect income, it is better for MSME actors to optimize the use of working hours because thus the level of products produced will increase.

Conflict of interest statement and funding sources

The authors declared that they have no competing interest.

\section{Statement of authorship}

The authors have a responsibility for the conception and design of the study. The authors have approved the final article.

\section{Acknowledgments}

The authors would like to thank the Editor of IRJMIS for their valuable time, support, and advice in completing the current study. 


\section{References}

AB, A. M. (2015). Peran Usaha Kecil Menengah (UKM) Dalam Meningkatkan Kesejahteraan Masyarakat Di Kec. Cebeureum Kab. Kuningan (Doctoral dissertation, IAIN Syekh Nurjati Cirebon).

Adhiatma, A. A. (2015). Pengaruh Modal Awal, Lama Usaha, Dan Jam Kerja Terhadap Pendapatan Pedagang Kayu Glondong Di Kelurahan Karang Kebagusan Kabupaten Jepara. Jurnal Ekonomi dan Bisnis Universitas Udayana.

Adhiatma, P. (2014). Studi Pola Pemberian Air Irigasi Berdasarkan Faktor Jarak sebagai Upaya Pemenuhan Kebutuhan Air di Daerah Irigasi Kedungkandang Kabupaten Malang.

Ahmad, K. (1996). Dasar-dasar manajemen Investasi. Penerbit Rineka Cipta.

Arka, S., \& Yasa, I. K. O. A. (2015). Pengaruh Pertumbuhan Ekonomi dan Disparitas Pendapatan Antardaerah terhadap Kesejahteraan Masyarakat Provinsi Bali. Jurnal Ekonomi Kuantitatif Terapan, 8(1).

Astuti, P. (2005). Pengaruh nilai marjin pemasaran terhadap pendapatan pengrajin gula kelapa di Desa Karangduren, Kecamatan Tengaran, Kabupaten Semarang (Doctoral dissertation, Universitas Negeri Semarang).

Badaruddin. (2006). Pemanfaatan Modal Sosial Dalam Upaya Peningkatan Kesejahteraan Keluarga Pada Komunitas Petani Karet di Kec.Kao Kab.Pasaman Sumatera Barat. Artikel Ilmiah Universitas Sumatera Barat.

Bire, A. R., Sauw, H. M., \& Maria, -. (2019). The effect of financial literacy towards financial inclusion through financial training. International Journal of Social Sciences and Humanities, 3(1), 186-192. https://doi.org/10.29332/ijssh.v3n1.280

Chou, Y. K. (2006). Three simple models of social capital and economic growth. The Journal of SocioEconomics, 35(5), 889-912. https://doi.org/10.1016/j.socec.2005.11.053

Dewi, I. G. A. A. O., Dewi, I. G. A. A. P., Kustina, K. T., \& Prena, G. D. (2018). Culture of tri hita karana on ease of use perception and use of accounting information system. International Journal of Social Sciences and Humanities, 2(2), 77-86. https://doi.org/10.29332/ijssh.v2n2.131

Dewi, M. Pengaruh Pendapatan Pada Konsumsi di Indonesia: Pengembangan Model Teoritis dan Pemilihan Model Empiris. Jurnal Ekonomi Kuantitatif Terapan, 8(1).

Dietsch, M. (1993). Economies of scale and scope in French commercial banking industry. Journal of Productivity Analysis, 4(1-2), 35-50. https://doi.org/10.1007/BF01073464

Eggert, A., Hogreve, J., Ulaga, W., \& Muenkhoff, E. (2014). Revenue and profit implications of industrial service strategies. Journal of Service Research, 17(1), 23-39. https://doi.org/10.1177\%2F1094670513485823

Fukuyama, F. (1995). Trust: The social virtues and the creation of prosperity.

Golden, L. (2012). The effects of working time on productivity and firm performance, research synthesis paper. International Labor Organization (ILO) Conditions of Work and Employment Series, (33).

Hyman, E. L. (1989). The role of small-and micro-enterprises in regional development. Project Appraisal, 4(4), 197214. https://doi.org/10.1080/02688867.1989.9726734

Kasmir, S., \& Carbonella, A. (2008). Dispossession and the anthropology of labor. Critique of Anthropology, 28(1), 5-25. https://doi.org/10.1177\%2F0308275X07086555

Korry, P. D. P., \& Suartini, N. W. (2019). Hedonism and culture toward impact of shopping behavior. International Journal of Social Sciences and Humanities, 3(1), 125-133. https://doi.org/10.29332/ijssh.v3n1.260

Kurniawan, J. (2016). Dilema Pendidikan dan Pendapatan di Kabupaten Grobogan. Jurnal Ekonomi Kuantitatif Terapan, 9(1).

Kustina, K. T., Dewi, I. G. A. A. O., Prena, G. D., \& Utari, I. G. A. D. (2018). MSMEs credit distribution and nonperforming loan towards banking companies profit in Indonesia. International Journal of Social Sciences and Humanities, 2(1), 10-23. https://doi.org/10.29332/ijssh.v2n1.72

Lisa, O., \& Hermanto, B. (2018). The effect of tax amnesty and taxpayer awareness to taxpayer compliance with financial condition as intervening variable. International Research Journal of Management, IT and Social Sciences, 5(2), 227-236.

Mulyadi, L. (2005). Pengadilan anak di Indonesia: teori, praktik, dan permasalahannya. Mandar Maju.

Narasimhulu, T. (2019). Impact of mgnregs on dalit women: A case study of nagari mandal in chittoor district. International Research Journal of Engineering, IT \& Scientific Research, 5(3), 14-27. https://doi.org/10.21744/irjeis.v5n3.644

Ovtchinnikov, A. V. (2010). Capital structure decisions: Evidence from deregulated industries. Journal of financial economics, 95(2), 249-274. https://doi.org/10.1016/j.jfineco.2009.10.003

Pariartha, I. W. W. Kontribusi modal dan jam kerja terhadap pendapatan pedagang di pasar umum pekutatan, kecamatan pekutatan, kabupaten jembrana. Piramida.

Prawira D., I. H., \& Dewi, H. U. (2019). The analysis of factors that effect business development and income of MSMEs in Denpasar city. International Research Journal of Management, IT and Social Sciences, 6(4), 118-126.

https://doi.org/10.21744/irjmis.v6n4.664 
Parinduri, R. A. (2014). Family hardship and the growth of micro and small firms in Indonesia. Bulletin of Indonesian Economic Studies, 50(1), 53-73. https://doi.org/10.1080/00074918.2014.896237

Paskarina, C. (2007). Kemitraan Pemerintah dan Swasta dalam Pelayanan Publik. Warta BAPPEDA, Bandung.

Pemayun, A. G. P., \& Suryanata, I. G. N. P. (2019). Tourism as leading sector for foreign exchange contributors with government policy efforts through visa-free visits in Bali. International Research Journal of Management, IT and Social Sciences, 6(1), 63-69. https://doi.org/10.21744/irjmis.v6n1.583

Prakoso, J. (2013). Peranan tenaga kerja, modal, dan teknologi terhadap peningkatan pendapatan masyarakat nelayan di desa asemdoyong kecamatan taman kabupaten pemalang (Doctoral dissertation, Universitas Negeri Semarang).

Raheman, A., \& Nasr, M. (2007). Working capital management and profitability-case of Pakistani firms. International review of business research papers, 3(1), 279-300.

Sriwati, N. K. (2011). Pengaruh modal kerja terhadap volume penjualan pada kantin irma di pt. poso energy desa sulewana kec. pamona utara. Jurnal Ilmiah EkoMen, 11(02).

Suartawan, I. G. N. P. A., \& Artini, L. G. S. (2019). A comparative study on domestic and foreign equity funds in Indonesia. International Research Journal of Management, IT and Social Sciences, 6(4), 54-61. https://doi.org/10.21744/irjmis.v6n4.642

Sudirman, I. W., \& Putra, I. P. D. (2015). Pengaruh Modal dan Tenaga Kerja terhadap Pendapatan dengan Lama Usaha sebagai Variabel Moderating. E-Jurnal Ekonomi Pembangunan Universitas Udayana, 4(9).

Sukirno, S. (2015). Makroekonomi: Teori Pengantar, Edisi 3 Cetakan ke-23. Raja GrafindoPersada. Jakarta.

Sukirno, S. dkk., 2012. Pengantar Bisnis Edisi Pertama, Kencana, Jakarta.

Sumarsono, H. (2016). Faktor-faktor yang mempengaruhi intensi wirausaha mahasiswa universitas muhammadiyah ponorogo. Ekuilibrium: Jurnal Ilmiah Bidang Ilmu Ekonomi, 8(1), 62-88.

Suparmoko, M. (1986). Inter-Governmental Finance in Indonesia. Economics and Finance in Indonesia, 34, 414-432. Suparmoko, M. (2000). Keuangan negara: Dalam teori dan praktek. BPFE.

Supriadi, Y., \& Puspitasari, R. (2012). Pengaruh Modal Kerja Terhadap Penjualan dan Profitabilitas Perusahaan pada PT. Indocement Tunggal Prakarsa Tbk. Jurnal Ilmiah Kesatuan, (1Vol), 14.

Thobias, E. (2013). Pengaruh modal sosial terhadap perilaku kewirausahaan (suatu studi pada pelaku usaha mikro kecil menengah di Kecamatan Kabaruan Kabupaten Kepulauan Talaud). Jurnal Acta Diurna, 2(2).

Utama, M. S. (2016). Aplikasi Analisis Kuantitatif untuk Ekonomi dan Bisnis. Denpasar: CV. Sastra Utama.

Widyamukti, E. Y., \& Wibowo, J. (2018). Pengaruh Modal Kerja Terhadap Penjualan Dan Laba Perusahaan (Studi Kasus pada Sektor Food and Beverage yang terdaftar di BEI 2011-2014). JEMAP, 1(1), 57-68.

Yanutya, P. A. T. (2013). Analisis Pendapatan Petani Tebu Di Kecamatan Jepon Kabupaten Blora. Economics Development Analysis Journal, 2(4).

Yuniartini, N. P. S. (2013). Pengaruh Modal, Tenaga Kerja dan Teknologi terhadap Produksi Industri Kerajinan Ukiran Kayu di Kecamatan Ubud. E-Jurnal Ekonomi Pembangunan Universitas Udayana, 2(2). 